\title{
Peramalan Data IHSG Menggunakan Fuzzy Time Series
}

\author{
Seng Hansun $*^{1}$ \\ ${ }^{1}$ Universitas Multimedia Nusantara; Jl. Boulevard Gading Serpong, telp.(021)54220808, \\ fax.(021)54220800 \\ e-mail: *1/hansun@unimedia.ac.id
}

\begin{abstract}
Abstrak
Fuzzy time series merupakan salah satu metode soft computing yang telah digunakan dan diterapkan dalam analisis data runtun waktu. Tujuan utama dari fuzzy time series adalah untuk memprediksi data runtun waktu yang dapat digunakan secara luas pada sembarang data real time, termasuk data pasar modal.

Banyak peneliti yang telah berkontribusi dalam pengembangan analisis data runtun waktu menggunakan fuzzy time series, seperti Chen dan Hsu [1], Jilani dkk. [2], serta Stevenson dan Porter [3]. Dalam penelitian ini, dicoba untuk menerapkan metode fuzzy time series pada salah satu indikator pergerakan harga saham, yakni data IHSG (Indeks Harga Saham Gabungan).

Kinerja metode yang diusulkan dievaluasi dengan menghitung tingkat akurasi dan tingkat kehandalan metode fuzzy time series yang diterapkan pada data IHSG. Melalui pendekatan ini, diharapkan metode fuzzy time series dapat menjadi alternatif untuk memprediksi data IHSG yang merupakan salah satu indikator pergerakan harga saham di Indonesia.
\end{abstract}

Kata kunci - fuzzy time series, data runtun waktu, soft computing, IHSG

\begin{abstract}
Fuzzy time series is one of the soft computing method that been used and implemented in time series analysis. The main goal of fuzzy time series is to predict time series data that can be used widely in any real time data, including stock market share.

Many researchers have contributed in the development of fuzzy time series analysis, such as Chen and Hsu [1], Jilani [2], and Stevenson and Porter [3]. In this research, we will try to implement the fuzzy time series method in one of the stock market change indicator, i.e. the Jakarta composite index or also known as IHSG (Indeks Harga Saham Gabungan).

The research is continued by calculating the accuracy and robustness of the method which has been implemented on IHSG data. By this approach, we hope it can be an alternative to predict the IHSG data which is an indicator of stock price changes in Indonesia.
\end{abstract}

Keywords - fuzzy time series, time series data, soft computing, IHSG

\section{PENDAHULUAN}

$D^{\text {san }}$ ta runtun waktu (time series) adalah suatu rangkaian pengamatan berdasarkan urutan waktu dari karakteristik kuantitatif dari satu atau kumpulan kejadian yang diambil dalam periode waktu tertentu [4]. Untuk memahami karakteristik-karakteristik yang dimiliki oleh data runtun waktu, para peneliti telah mengadopsi metode-metode analisis data runtun waktu (time series

Received March 28 ${ }^{\text {th }}$,2012; Revised June 20 ${ }^{\text {th }}$,2012; Accepted June 29 ${ }^{\text {th }}, 2012$ 
analysis) yang salah satu tujuannya tidak lain adalah untuk menemukan suatu keteraturan atau pola yang dapat digunakan dalam peramalan kejadian mendatang $[5,6,7]$.

Untuk memroses data runtun waktu, berbagai teknik soft computing seperti sistem fuzzy, jaringan saraf (neural networks), algoritma genetika (genetic algorithm) dan hybrid banyak dikembangkan oleh para peneliti dewasa ini. Khususnya, pendekatan dengan menggunakan sistem fuzzy banyak dikembangkan oleh para peneliti, seperti: Chen dan Hsu [1] yang memperkenalkan metode baru dalam peramalan data penerimaan mahasiswa baru Universitas Alabama; Jilani dkk. [2] yang menggunakan pendekatan fuzzy metric untuk peramalan fuzzy time series; Stevenson dan Porter [3] yang memanfaatkan persentase perubahan data sebagai semesta pembicaraan dalam peramalan data runtun waktu dengan fuzzy time series; Popoola dkk. [8,9], serta Hansun dan Subanar [10,11] yang menggunakan metode hybrid fuzzy-wavelet dalam peramalan data runtun waktu.

Pada penelitian ini, peneliti mencoba untuk menerapkan metode fuzzy time series dalam peramalan data IHSG (Indeks Harga Saham Gabungan). Dengan peramalan data IHSG ini, para pelaku pasar dapat memprediksi kenaikan atau penurunan harga saham di masa mendatang. Untuk menghitung tingkat akurasi dan kehandalan peramalan data runtun waktu IHSG, peneliti akan menggunakan kriteria MSE (Mean Square Error) dan MAPE (Mean Absolute Percentage Error).

\section{METODE PENELITIAN}

Dalam peramalan data runtun waktu IHSG, peneliti menggunakan dasar fuzzy time series sebagai metode peramalan dan kriteria MSE dan MAPE untuk mengukur tingkat akurasi serta kehandalan hasil peramalan yang dilakukan.

\subsection{Analisis Data Runtun Waktu}

Menurut Render dkk. [7], analisis data runtun waktu (time series) berarti memecah data lampau menjadi komponen-komponen dan memproyeksikannya ke depan (forecasting). Dengan kata lain, tujuan analisis data runtun waktu adalah mengindentifikasi komponen faktor yang dapat memengaruhi nilai dalam deret data, sehingga dapat digunakan untuk peramalan baik jangka pendek maupun jangka panjang [5].

Pada umumnya, suatu data runtun waktu dapat terdiri atas satu atau beberapa komponen dari empat komponen utama berikut:

\section{a. Trend (T)}

Trend adalah komponen jangka panjang yang menunjukkan kenaikan atau penurunan dalam data runtun waktu untuk suatu periode waktu tertentu. Dengan lebih sederhana, dapat dinyatakan bahwa trend adalah suatu garis halus atau kurva yang menunjukkan suatu kecenderungan umum dari suatu data runtun waktu [6]. Misalnya adalah kenaikan produksi, inflasi, dan perubahan populasi.

b. Siklus (Cycles/ C)

Komponen siklus adalah deret tidak beraturan berupa fluktuasi gelombang atau siklus dengan durasi waktu yang panjang. Komponen ini biasanya berhubungan dengan siklus bisnis (business cycle), dimana suatu gerakan dianggap sebagai siklus apabila timbul kembali setelah jangka waktu lebih dari satu tahun. Contoh data runtun waktu dengan komponen siklus adalah data kondisi perekonomian yang perubahannya lebih dari satu tahun.

c. Musiman (Seasonality/ S)

Komponen musiman adalah suatu pola dari fluktuasi permintaan (demand) di atas atau di bawah garis trend yang terjadi tiap tahunnya. Fluktuasi musiman yang dimaksud dapat diklasifikasikan secara kuartal, bulanan, mingguan, atau harian, dan mengarah pada pola yang berubah secara regular dalam suatu waktu. Misalnya kenaikan harga bahan-bahan pokok yang terjadi menjelang Hari Raya Idul Fitri tiap tahun, dan sebagainya.

IJCCS Vol. 6, No. 2, July 2012: $79-88$ 


\section{d. Irregular (I)}

Komponen irregular adalah gerakan sporadis atau fluktuasi yang diakibatkan oleh kejadian yang tidak dapat diprediksi atau kejadian non-periodik, seperti terjadinya perang, bencana alam, dan lain sebagainya.

Dalam Statistika, ada dua bentuk umum dari pemodelan data runtun waktu. Model yang pertama adalah multiplicative model yang mengasumsikan bahwa data berkala $\mathbf{Y}$ merupakan hasil perkalian dari keempat komponen yang telah dijelaskan sebelumnya, yaitu

$$
Y=T \times C \times 5 \times I
$$

Model kedua adalah additive model yang menggunakan operator penjumlahan untuk menjumlahkan keempat komponen data runtun waktu dan dinyatakan dalam bentuk persamaan berikut:

$$
Y=T+C+5+I .
$$

Selain itu, dalam analisis data runtun waktu, asumsi penting yang biasanya digunakan adalah stasioneritas data. Stasioneritas ini dimaksudkan dengan mean dan variansi data runtun waktu yang konstan, dan digunakan untuk menarik kesimpulan mengenai struktur dari suatu proses stokastik berdasarkan jumlah pengamatan yang terbatas. Namun pada kenyataannya, banyak data runtun waktu yang bersifat tidak stasioner, baik dalam mean maupun varians. Ketidak-stasioneran dalam varians dapat diatasi dengan melakukan transformasi, sementara ketidak-stasioneran dalam mean biasanya ditandai dengan adanya suatu trend [5].

\subsection{Fuzzy Time Series}

Pada perkembangan sistem fuzzy, Chen dan Hsu [1], Jilani dkk. [2], serta Stevenson dan Porter [3] telah memperkenalkan dan mengembangkan suatu metode peramalan data runtun waktu yang menggunakan sistem inferensi fuzzy dengan basis yang diperkenalkan oleh Wang dan Mendel [12,13]. Metode tersebut dikenal sebagai fuzzy time series.

Berikut langkah-langkah penerapan fuzzy time series [2,3]:

1. Definisikan himpunan semesta $U$ dan bagi menjadi beberapa interval $u_{1}, u_{2}, \ldots, u_{n}$ dengan panjang yang sama. Himpunan semesta yang digunakan adalah persentase perubahan data runtun waktu $i$ ke $i+1$.

2. Tentukan kepadatan distribusi dari persentase perubahan data runtun waktu dengan mengurutkan data tersebut ke dalam interval yang bersesuaian. Selanjutnya tentukan jumlah data yang terdapat dalam masing-masing interval.

Temukan interval yang memiliki jumlah data terbanyak dan bagi menjadi empat sub interval dengan panjang yang sama. Kemudian bagi interval yang memiliki jumlah data terbanyak kedua menjadi tiga sub interval dengan panjang yang sama. Interval yang memiliki jumlah data terbanyak ketiga dibagi menjadi dua sub interval dengan panjang yang sama. Untuk interval-interval lainnya, biarkan seperti semula.

3. Definisikan himpunan-himpunan fuzzy $A_{i}$ berdasarkan interval yang terbentuk dan fuzzifikasi persentase perubahan data runtun waktu tersebut. Himpunan fuzzy $A_{i}$ menunjukkan variabel linguistik dari persentase perubahan data runtun waktu. Seperti dalam Chen dan Hsu [1] digunakan fungsi keanggotaan segitiga untuk mendefinisikan himpunan-himpunan fuzzy $A_{\bar{i}}$, seperti yang ditunjukkan di langkah berikutnya.

4. Defuzzifikasi data fuzzy dengan menggunakan rumus peramalan berikut [2]: 


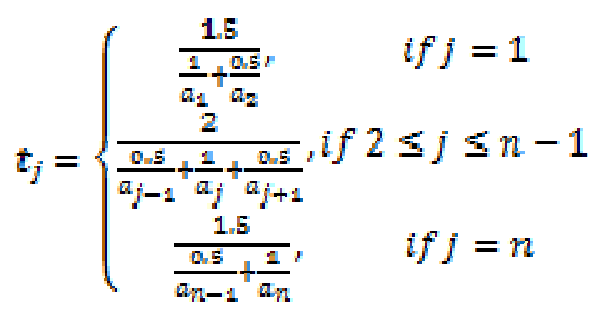

dimana $a_{j-1}, a_{j}, a_{j+1}$ merupakan titik-titik tengah dari interval fuzzy $A_{j-1}, A_{j}, A_{j+1}$ secara berurutan. $t_{j}$ menunjukkan persentase perubahan data runtun waktu hasil peramalan. Selanjutnya, persentase hasil peramalan tersebut digunakan untuk menentukan data runtun waktu hasil peramalan.

\subsection{Mean Square Error (MSE)}

Kriteria MSE menyatakan besarnya kesalahan rata-rata kuadrat dari suatu metode peramalan, dengan rumus perhitungan

$$
M S E=\frac{\sum_{E=1}^{n} \theta_{2}^{n}}{n}
$$

dimana $n$ menyatakan jumlah data dan $e_{t}$ adalah nilai kesalahan hasil ramalan yang diperoleh dari $X_{t}-\hat{X}_{t}$ Dalam hal ini, $X_{t}$ adalah nilai data aktual dan $\hat{X}_{t}$ adalah nilai ramalannya.

\subsection{Mean Absolute Percentage Error (MAPE)}

Nilai MAPE memberikan petunjuk mengenai seberapa besar rata-rata kesalahan absolut peramalan dibandingkan dengan nilai sebenarnya, dan dinyatakan dengan rumus

$$
\text { MAPE }=\frac{\sum_{t=1}^{n}\left|\frac{E_{t}}{x_{t}}\right|}{n} \times 100
$$

dimana $n$ adalah jumlah data dan $e_{t}$ adalah nilai kesalahan ramalan yang diperoleh dari $X_{t}-\hat{X}_{t}$. Nilai data aktual dinotasikan dengan $X_{t}$ dan $\hat{X}_{t}$ adalah nilai ramalannya.

\subsection{Arsitektur Sistem}

Untuk menerapkan fuzzy time series pada data IHSG, peneliti mengembangkan sebuah sistem dengan memanfaatkan Visual Basic.NET pada sistem operasi Windows 7 Professional 32-bit. Adapun lingkungan perangkat keras yang digunakan dalam pengembangan dan pembangunan sistem adalah sebagai berikut:

1. Prosesor Intel ${ }^{\circledR}$ Core $^{\mathrm{TM}} 2$ Duo

2. Memori 2048MB RAM

3. Hard disk dengan kapasitas $160 \mathrm{~GB}$

4. Layar monitor 12.1"

5. Keyboard

6. Mouse

Gambar 1 memperlihatkan diagram alir sistem. Sistem yang dibangun dapat menerima data masukan (input data) dari suatu data runtun waktu yang sebelumnya telah disimpan dalam format Microsoft Excel ('.xls' dan 'xlsx'). Selanjutnya program akan menjalankan proses komputasi sesuai dengan langkah-langkah metode fuzzy time series yang telah dijelaskan sebelumnya untuk data yang diberikan. Hasil peramalan data dengan fuzzy time series kemudian ditampilkan dan dianalisis terhadap data aktual untuk mengetahui tingkat akurasi dan tingkat kehandalan hasil peramalan. 


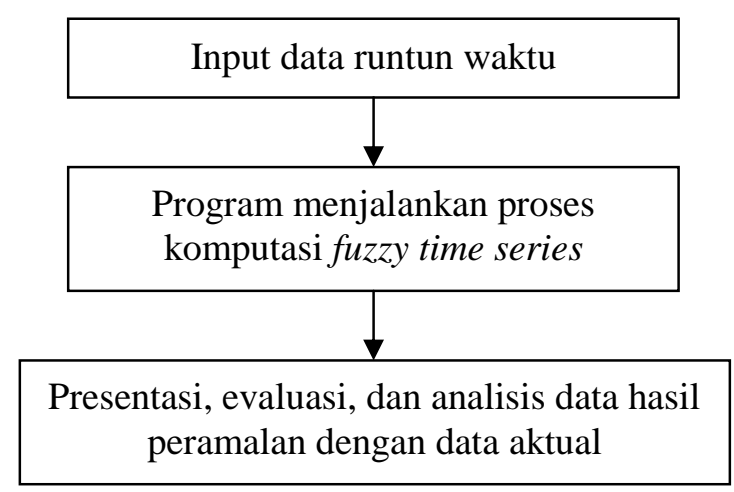

Gambar 1 Gambaran Umum Perangkat Lunak

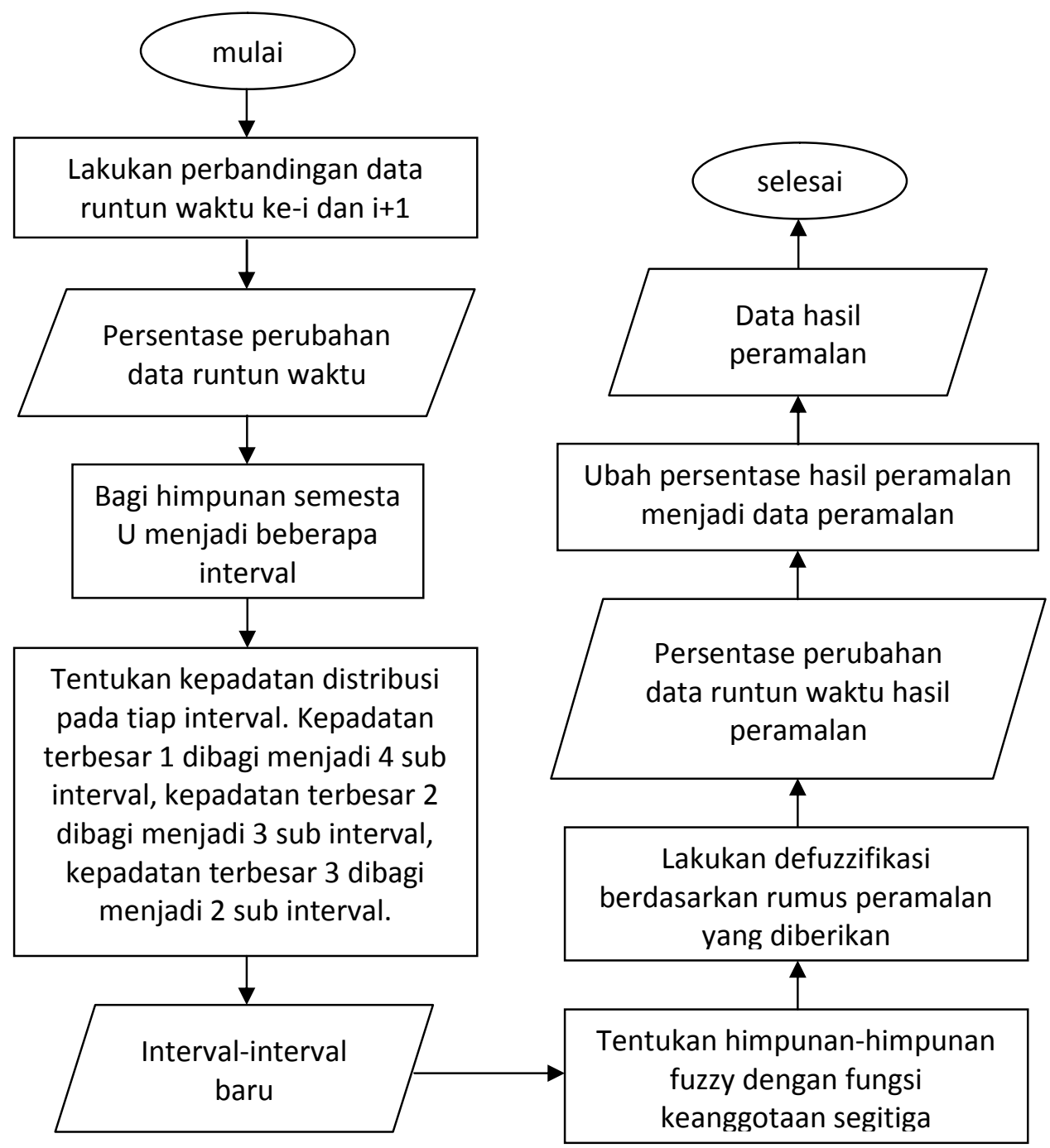

Gambar 2 Diagram Alir Peramalan dengan Fuzzy Time Series

Gambar 2 memperlihatkan diagram alir peramalan dengan menggunakan metode fuzzy time series. Langkah-langkah peramalan dilakukan sebagaimana yang telah dijelaskan sebelumnya pada sub bab 2.2 mengenai Fuzzy Time Series, dengan menggunakan persentase perubahan data sebagai semesta pembicaraan. 


\section{HASIL DAN PEMBAHASAN}

Melalui langkah-langkah peramalan yang telah dijelaskan di atas, fuzzy time series diterapkan pada data IHSG. Jumlah data yang digunakan adalah sebanyak 30 data IHSG, yang direkam sejak 22 Agustus 2012 hingga 19 Maret 2012 secara mingguan. Jumlah interval awal yang digunakan dalam peramalan fuzzy time series adalah 7 interval. MSE digunakan untuk mengukur tingkat akurasi hasil peramalan, sedangkan MAPE digunakan untuk mengukur kehandalan metode peramalan dalam peramalan data IHSG.

Gambar 3 memperlihatkan antarmuka sistem yang telah dibangun oleh peneliti untuk menerima masukan data IHSG. Tiga puluh data IHSG yang telah direkam ditampilkan pada sisi kiri antarmuka sistem, sementara grafik data IHSG yang di-input diperlihatkan pada sisi kanan antarmuka sistem. Interval awal yang digunakan sebanyak 7 interval.

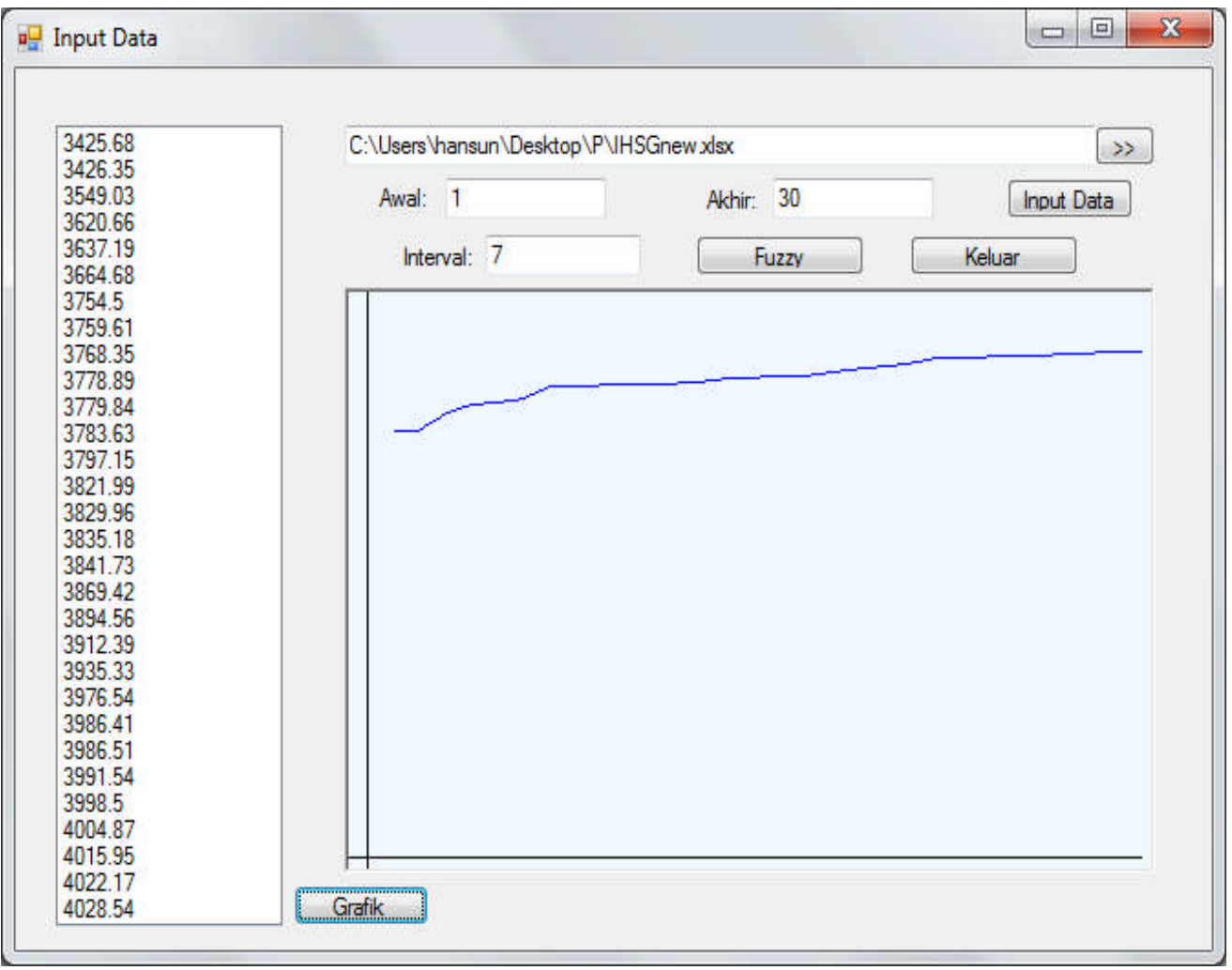

Gambar 3 Antarmuka Awal Sistem

Grafik hasil peramalan data IHSG dengan menggunakan fuzzy time series dapat dilihat pada Gambar 4. Dari Gambar 4, terlihat bahwa data hasil peramalan (ditunjukkan dengan garis berwarna merah) hampir mendekati data asli IHSG yang digunakan (ditunjukkan dengan warna biru). Dengan menggunakan interval awal sebanyak 7 interval, ternyata terbentuk 15 sub interval sebagai domain himpunan fuzzy yang akan digunakan dalam sistem. 


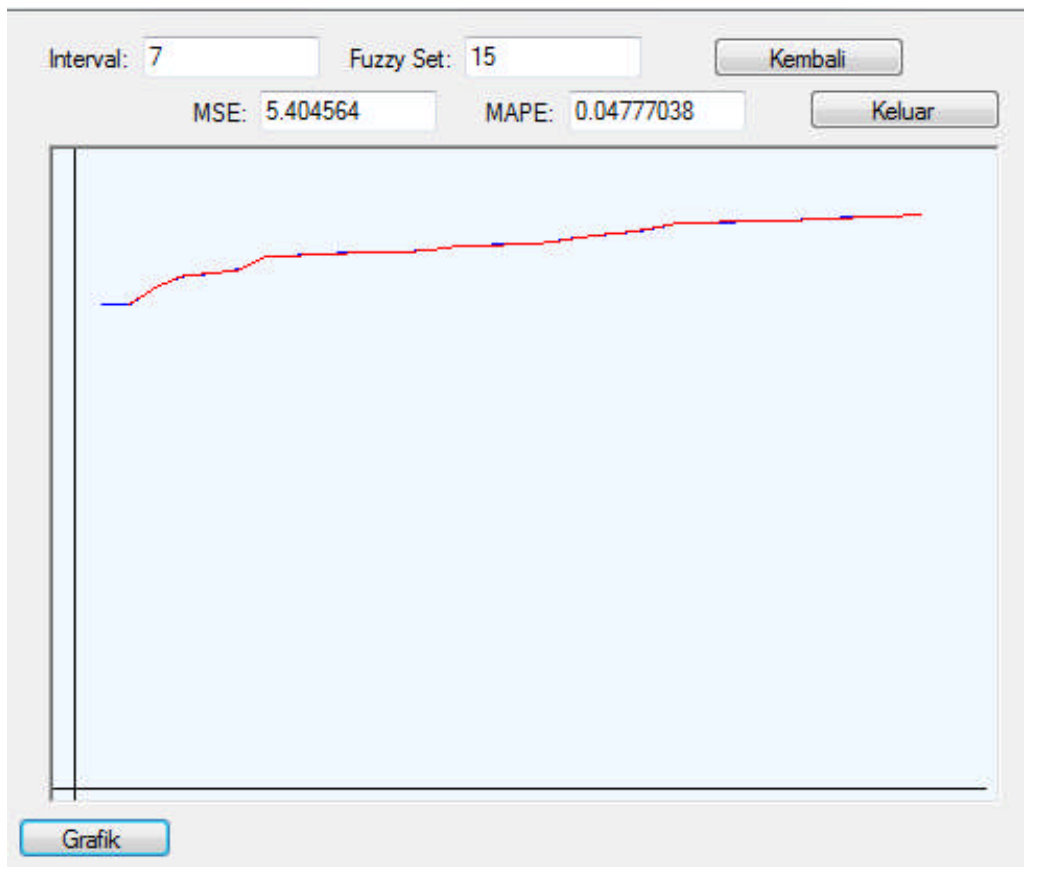

Gambar 4 Grafik Data IHSG dan Hasil Peramalannya

Catatan:

1. Warna biru menunjukkan data sebenarnya

2. Warna merah menunjukkan data hasil peramalan

Pada Tabel 1, dapat dilihat data IHSG hasil peramalan dengan menggunakan fuzzy time series. Dari tabel tersebut terlihat bahwa dengan menggunakan interval awal sebanyak 7 interval, peramalan memberikan nilai MSE dan MAPE yang cukup kecil. Nilai MSE sebesar 5.404564 dan MAPE sebesar 0.04777038. Hal ini menunjukkan metode fuzzy time series dapat dengan baik meramal data IHSG sebagai salah satu indikator pergerakan harga saham di Indonesia.

Tabel 1 Hasil Peramalan Data IHSG

\begin{tabular}{cccccccc}
\hline Date & \multirow{2}{*}{ Data } & $\begin{array}{c}\text { Percen } \\
\text {-tage }\end{array}$ & $\begin{array}{c}\text { Fuzzy } \\
\text { Set }\end{array}$ & $\begin{array}{c}\text { Predicted } \\
\text { Percentage }\end{array}$ & Forecast & $\left(\mathcal{X}_{t}-\hat{X}_{t}\right)^{2}$ & $\frac{\left|X_{t}-\hat{X}_{t}\right|}{X_{t}}$ \\
\hline $8 / 22 / 2011$ & 3425.68 & & & & & & \\
$9 / 5 / 2011$ & 3426.35 & $0.02 \%$ & $\mathrm{X}_{1}$ & $0.09 \%$ & 3428.826 & 6.1297345 & 0.07225852 \\
$9 / 12 / 2011$ & 3549.03 & $3.58 \%$ & $\mathrm{X}_{14}$ & $3.52 \%$ & 3546.84326 & 4.7819523 & 0.06161592 \\
$9 / 19 / 2011$ & 3620.66 & $2.02 \%$ & $\mathrm{X}_{10}$ & $2.12 \%$ & 3624.39868 & 13.978397 & 0.10326210 \\
$9 / 26 / 2011$ & 3637.19 & $0.46 \%$ & $\mathrm{X}_{4}$ & $0.48 \%$ & 3638.109 & 0.8444605 & 0.02526525 \\
$10 / 3 / 2011$ & 3664.68 & $0.76 \%$ & $\mathrm{X}_{5}$ & $0.65 \%$ & 3660.78247 & 15.190201 & 0.10635200 \\
$10 / 10 / 2011$ & 3754.5 & $2.45 \%$ & $\mathrm{X}_{11}$ & $2.41 \%$ & 3753.059 & 2.0762445 & 0.03837842 \\
$10 / 17 / 2011$ & 3759.61 & $0.14 \%$ & $\mathrm{X}_{1}$ & $0.09 \%$ & 3757.948 & 2.7626075 & 0.04420962 \\
$10 / 24 / 2011$ & 3768.35 & $0.23 \%$ & $\mathrm{X}_{2}$ & $0.15 \%$ & 3765.3645 & 8.913782 & 0.07922819 \\
$10 / 31 / 2011$ & 3778.89 & $0.28 \%$ & $\mathrm{X}_{2}$ & $0.15 \%$ & 3774.118 & 22.771722 & 0.12627975 \\
$11 / 7 / 2011$ & 3779.84 & $0.03 \%$ & $\mathrm{X}_{1}$ & $0.09 \%$ & 3782.36035 & 6.351729 & 0.06667646 \\
$11 / 14 / 2011$ & 3783.63 & $0.10 \%$ & $\mathrm{X}_{1}$ & $0.09 \%$ & 3783.31128 & 0.1015082 & 0.00842057 \\
$11 / 21 / 2011$ & 3797.15 & $0.36 \%$ & $\mathrm{X}_{3}$ & $0.33 \%$ & 3795.96777 & 1.39742875 & 0.03113200 \\
$11 / 28 / 2011$ & 3821.99 & $0.65 \%$ & $\mathrm{X}_{5}$ & $0.65 \%$ & 3821.78 & 0.04408359 & 0.00549349
\end{tabular}




\begin{tabular}{cccccccc}
$12 / 5 / 2011$ & 3829.96 & $0.21 \%$ & $\mathrm{X}_{2}$ & $0.15 \%$ & 3827.84 & 4.49386168 & 0.0553497449 \\
$12 / 12 / 2011$ & 3835.18 & $0.14 \%$ & $\mathrm{X}_{1}$ & $0.09 \%$ & 3833.47729 & 2.8989718 & 0.0443952233 \\
$12 / 19 / 2011$ & 3841.73 & $0.17 \%$ & $\mathrm{X}_{2}$ & $0.15 \%$ & 3841.05 & 0.46230703 & 0.0176985785 \\
$12 / 27 / 2011$ & 3869.42 & $0.72 \%$ & $\mathrm{X}_{5}$ & $0.65 \%$ & 3866.64941 & 7.67571354 & 0.07160008 \\
$1 / 3 / 2012$ & 3894.56 & $0.65 \%$ & $\mathrm{X}_{5}$ & $0.65 \%$ & 3894.5188 & 0.00170236 & 0.0010594204 \\
$1 / 9 / 2012$ & 3912.39 & $0.46 \%$ & $\mathrm{X}_{4}$ & $0.48 \%$ & 3913.329 & 0.8821135 & 0.0240060166 \\
$1 / 16 / 2012$ & 3935.33 & $0.59 \%$ & $\mathrm{X}_{5}$ & $0.65 \%$ & 3937.76758 & 5.94140625 & 0.061938893 \\
$1 / 24 / 2012$ & 3976.54 & $1.05 \%$ & $\mathrm{X}_{7}$ & $1.06 \%$ & 3977.02051 & 0.23085022 & 0.0120825833 \\
$1 / 30 / 2012$ & 3986.41 & $0.25 \%$ & $\mathrm{X}_{2}$ & $0.15 \%$ & 3982.62646 & 14.3144732 & 0.09490863 \\
$2 / 6 / 2012$ & 3986.51 & 0.003 & $\mathrm{X}_{1}$ & $0.09 \%$ & 3990.0708 & 12.6792326 & 0.08932101 \\
$2 / 13 / 2012$ & 3991.54 & $0.13 \%$ & $\mathrm{X}_{1}$ & $0.09 \%$ & 3990.17114 & 1.87387753 & 0.034294948 \\
$2 / 21 / 2012$ & 3998.5 & $0.17 \%$ & $\mathrm{X}_{2}$ & $0.15 \%$ & 3997.64966 & 0.7230812 & 0.02126652 \\
$2 / 27 / 2012$ & 4004.87 & $0.16 \%$ & $\mathrm{X}_{2}$ & $0.15 \%$ & 4004.62 & 0.0625 & 0.0062424 \\
$3 / 5 / 2012$ & 4015.95 & $0.28 \%$ & $\mathrm{X}_{2}$ & $0.15 \%$ & 4011 & 24.5020161 & 0.123257294 \\
$3 / 12 / 2012$ & 4022.17 & $0.16 \%$ & $\mathrm{X}_{2}$ & $0.15 \%$ & 4022.097 & 0.00532871 & 0.0018148921 \\
& & & & & & 5 & 7 \\
$3 / 19 / 2012$ & 4028.54 & $0.16 \%$ & $\mathrm{X}_{2}$ & $0.15 \%$ & 4028.32642 & 0.04563480 & 0.005302741 \\
\hline & & & & & & 62 & MSE $=$ \\
\hline
\end{tabular}

\section{KESIMPULAN}

Berdasarkan hasil penelitian, pengembangan sistem, dan analisa data yang telah dilakukan, dapat ditarik beberapa kesimpulan sebagai berikut:

1. Metode peramalan fuzzy time series memberikan hasil peramalan yang cukup baik untuk peramalan data IHSG. Hal ini dapat dilihat dari nilai Mean Square Error (MSE) dan Mean Absolute Percentage Error (MAPE) yang cukup kecil, yakni 5.404564 untuk MSE dan 0.04777038 untuk MAPE.

2. Jumlah interval awal yang digunakan sebanyak 7 interval telah dapat memberikan hasil peramalan yang cukup baik. Pada penelitian lebih lanjut, dapat dilakukan perbandingan jumlah interval terbaik yang diperlukan dalam peramalan data IHSG menggunakan metode fuzzy time series.

3. Para pelaku pasar dapat memanfaatkan hasil peramalan data IHSG dengan menggunakan fuzzy time series untuk memperkirakan pergerakan harga saham di masa mendatang.

\section{SARAN}

Melalui hasil kajian dan penelitian yang telah dilakukan, beberapa saran yang dapat diberikan untuk pengembangan penelitian lebih lanjut adalah sebagai berikut:

1. Membandingkan tingkat akurasi dan tingkat kehandalan hasil peramalan menggunakan fuzzy time series untuk data IHSG dengan menggunakan berbagai interval awal yang berbeda. 
2. Membandingkan kehandalan dan tingkat akurasi metode fuzzy time series dengan metode peramalan konvensional lainnya, seperti Moving Average (MA), Weighted Moving Average (WMA), Auto Regressive Moving Average (ARMA), dan Auto Regressive Integrated Moving Average (ARIMA) pada peramalan data runtun waktu IHSG.

3. Membandingkan kehandalan dan tingkat akurasi metode fuzzy time series dengan metode peramalan hybrid fuzzy lainnya, seperti metode hybrid fuzzy-wavelet dan Adaptive NeuroFuzzy Inference System (ANFIS) pada peramalan data runtun waktu IHSG.

4. Melakukan analisis penerapan metode fuzzy time series terhadap data runtun waktu yang bersifat nonlinear.

\section{DAFTAR PUSTAKA}

[1] Chen, S.-M. dan Hsu, C.-C., 2004, A New Method to Forecast Enrollments Using Fuzzy Time Series, International Journal of Applied Science and Engineering, 2, 3, 234-244.

[2] Jilani, T.A., Burney S.M.A., dan Ardil C., 2007, Fuzzy Metric Approach for Fuzzy Time Series Forecasting based on Frequency Density Based Partitioning, World Academy of Science, Engineering and Technology, 34, 1-6.

[3] Stevenson, M. dan Porter, J.E., 2009, Fuzzy Time Series Forecasting Using Percentage Change as the Universe of Discourse, World Academy of Science, Engineering and Technology, 27, 55, 154-157, http://www.waset.org/journals/waset/v55/.

[4] OECD: Glossary of Statistical Terms, http://stats.oecd.org/glossary/about.asp, diakses 20 Maret 2012.

[5] Subanar dan Suhartono, 2009, Wavelet Neural Networks untuk Peramalan Data Time Series Finansial, Program Penelitian Ilmu Dasar Perguruan Tinggi, FMIPA UGM, Yogyakarta.

[6] Boediono dan Koster, W., 2001, Teori dan Aplikasi Statistika dan Probabilitas, PT. Remaja Rosdakarya, Bandung.

[7] Render, B., Stair Jr., R.M. dan Hanna, M.E., 2003, Quantitative Analysis for Management, $8^{\text {th }}$ edition, Pearson Education, Inc., New Jersey.

[8] Popoola, A., Ahmad, S. dan Ahmad, K., 2004, A Fuzzy-Wavelet Method for Analyzing Non-Stationary Time Series, Proc. of the $5^{\text {th }}$ International Conference on Recent Advances in Soft Computing RASC2004, Nottingham, United Kingdom, 231-236.

[9] Popoola, A.O., 2007, Fuzzy-Wavelet Method for Time Series Analysis, Disertasi, Department of Computing, School of Electronics and Physical Sciences, University of Surrey, Surrey.

[10] Hansun, S., 2011, Penerapan Pendekatan Baru Metode Fuzzy-Wavelet dalam Analisis Data Runtun Waktu, Prosiding Seminar Nasional Ilmu Komputer (SEMINASIK) GAMA, Yogyakarta, Indonesia, November 11.

[11] Hansun, S., 2011, Penerapan Pendekatan Baru Metode Fuzzy-Wavelet dalam Analisis Data Runtun Waktu, Tesis, Program Pasca Sarjana Ilmu Komputer, Universitas Gadjah Mada, Yogyakarta. 
[12] Wang, L.-X. dan Mendel, J.M., 1992, Generating Fuzzy Rules by Learning from Examples, IEEE Transactions on Systems, Man, and Cybernatics, 22, 6, 1414-1427.

[13] Wang, L.-X., 1996, A Course in Fuzzy Systems and Control, Prentice-Hall International, Inc., United States of America. 